\section{College and Career Readiness in Elementary Schools}

\author{
Nicole Pulliam ${ }^{a,{ }^{*}}$, Samantha Bartek ${ }^{a}$
}

\author{
Received: 14 September 2017 \\ Revised: 20 October 2017 \\ Accepted: 25 November 2017 \\ ISSN: 1307-9298 \\ Copyright (C) IEJEE \\ www.iejee.com
}

DOI: 10.26822/iejee.2018336193

\begin{abstract}
This conceptual article will provide an in-depth exploration of the relevant literature focused on college and career readiness interventions in elementary schools. Beginning with a theoretical framework, a rationale is provided for early intervention by elementary school counselors. While professional guidelines and standards exist supporting early college and career readiness interventions, research outlining evidencebased practices at the elementary level is scarce. Existing practices used by school counselors are outlined.
\end{abstract}

Keywords: Career development, college and career readiness, elementary education

\section{Introduction}

Career development describes "the lifelong psychological and behavioral processes as well as contextual influences shaping one's career over the life span" (Niles \& Harris-Bowlsbey, 2005, p 12). During the elementary years, students are at a crucial period when career beliefs and aspirations are being developed (Mariani, Berger, Koerner, \& Sandlin, 2016). While scarce, studies exist citing the significance of career-related decisions occuring during the elementary years. One study cited a large number of participants aged 9-10 who believed they already made decisions related to career aspirations (Seligman, Weinstock, \& Heflin, 1991). In another study, adults aged 40-55 explained that they made career-related decisions about their current professions during early childhood (Trice \& McClellan, 1994). Evidence supporting the need for evidence-based career counseling interventions for elementary students has increased in the research literature, though it remains highly underrepresented, with the majority focused on middle and high school interventions (Knight, 2015; Mariani et al., 2016; Woods \& Kaszubowski, 2008).

Interventions focused on college and career readiness have gained traction in the literature, noting the importance related to the development of a collegegoing mindset and in-depth career exploration as early as elementary school (Knight, 2015; Mariani et al., 2016). Recent predictions highlight the importance of both college and career readiness interventions (Carnevale, Smith, \& Strohl, 2010), noting that by $2020,65 \%$ of jobs in the nation will require some form of postsecondary education; however, the U.S. is predicted to be short of five million workers for these jobs by then (Carnevale, Smith, \& Strohl, 2014). Job outlook has continuously been stronger for those with postsecondary education, leading to increased income potential. Initiatives such as the North Star Goal launched in 2010 by the Obama administration, which aimed to make the U.S. a leader in postsecondary degree completion, and the Reach Higher Initiative (Reach Higher, 2015) led by former First Lady Michelle Obama focused on the goal of postsecondary access and success. As a result, many states across the country now require career planning before middle school (NOSCA, 2012). School counselors play a significant role in assisting students with career exploration and college readiness. The American School Counselor Association's National Model (ASCA, 2003) described a comprehensive school counseling program as a program addressing the needs of children beginning as early as pre-kindergarten through $12^{\text {th }}$ grade in three domains: academic, career, and personal/social. The career domain highlights the significance of developing skills to locate, evaluate, and interpret career information. Additionally, the career domain includes competencies demonstrating how interests, abilities, and achievement lead to achieving personal, social, educational, and career goals (ASCA, 2003). Since we know that elementary-aged children begin to make career-related choices that influence their future career goals, it is imperative that elementary school counselors become more involved in career-related interventions early on (Mariani et al., 2016; Woods \& Kaszubowski, 2008).

\footnotetext{
* Corresponding author: Nicole Pulliam, Monmouth University, Department of Educational Counseling and Leadership, 400 Cedar Avenue, West Long Branch, New Jersey, 07764, USA. Email: npulliam@monmouth.edu 
In a qualitative study ( $n=123)$ conducted with first-, third, and fifth-grade children to examine the types of careers they wished and expected to have (Auger, Blackhurst, \& Wahl, 2005), results showed that the younger children held more gender specific career expectations (i.e., female students as teachers; male students as truck drivers) while older elementary-aged students aspired to occupations based merely on fantasy. In another study $(n=150)$, the career development needs of fourth-grade students from two rural school districts (Wood \& Kaszubowski, 2008) were explored using a scale to measure Donald Super's nine dimensions (Super, 1990) of career development during the growth stage, the period when students fantasize and develop likes/dislikes and abilities/potential relating to careers. Results highlighted the gender disparity related to levels of career curiosity, comprehension of career information, and identification of key career figures that were matched with their career aspirations. Male students in particular scored significantly lower in the area of career curiosity (Woods \& Kaszubowski, 2008).

Another study $(n=115)$ showed glaring gender disparities (Blackhurst \& Auger, 2008) with respect to elementary and middle school-aged students' career aspirations and expectations for their futures. Results revealed that female students were more likely than their male counterparts to aspire to careers that require a college education, more likely to emphasize career advancement in their rationale for attending college, and less likely to choose sex-typed occupations. There is a clear need for additional discussion about early career interventions and the training provided to elementary school counselors.

\section{Theoretical Framework}

In the classic work written by Frank Parsons (1909, p.4), Parsons noted, "We guide our boys and girls to some extent through school, then drop them into this complex world to sink or swim as the case may be. Yet there is no part of life where the need for guidance is more empathic than in the transition from school to work-the choice of vocation, adequate preparation for it, and the attainment of efficiency and success." While Parsons's work, which contributed to the formation of school counseling, spoke directly to the importance of career counseling with youth in general, the contributions by later career theorists provide impetus for early career interventions. Several career development theories provide an understanding of career development from a developmental perspective, describing career development as a life-long process that begins as early as childhood (Super, 1990; Ginzberg, 1952; Ginzberg, Ginsburg, Alexrad, \& Herma, 1951; Gottfredson, 1981), while other theories posit that early childhood includes merely a fantasy stage related to career aspirations (Ginzberg, 1952). For the purpose of this article, career development theories focused on a developmental perspective will be discussed and can serve as helpful for elementary school counselors when providing guidance in understanding career paths and aspirations.

Donald Super's Life-Span, Life-Space Theory
Donald Super (1990) was one of the first developmental theorists to highlight career development as a process that unfolds gradually over the life span. Consisting of developmental stages and tasks, Super's Life-span, Lifespace approach to career development provides clear concepts that can be considered during college and career readiness planning for elementary students. At its core, the principle of "know thyself" is at the foundation of Super's approach, including concepts such as self-awareness, self-esteem, self-concept, and selfknowledge (Zunker, 2006). In addition, Super suggested that students gain career maturity as they get to know themselves better, leading to more informed career and future planning. Super also suggested that school curriculum offer opportunities for students to make connections between classroom activities and future work roles. This, he believed could provide students with the necessary opportunities to learn more about themselves and, in turn, learn to expand career considerations or at least to be more confident about their early career choices (Super, 1990).

Elementary students fall into Super's growth stage (Super, 1990) of career development (birth to age 14). This stage is characterized by development of capacity, attitudes, interests, and needs associated with selfconcepts. While this stage could also include middle school-aged students, the significance of early career development focus remains. During the elementary years, students formulate sets of self-concepts by way of interrelationships with peers, teachers, and other adults, while participating in curriculum requirements (Zunker, 2006). These activities, according to Super (1990), serve as the foundation for career maturity during the early elementary years.

\section{Gottfredson's Theory of Circumscription, Compromise, and Self-Creation}

Gottfredson's (1981) developmental theory of circumscription, compromise, and self-creation explains the formation of career aspirations. At its core, Gottfredson's theory describes how people become attracted to certain occupations. Similar to Super, Gottfredson believes self-concept to be a key factor in career selection, that is; people choose careers that are compatible with their self-images. Gottfredson posits that by the age of five, children's career aspirations begin to be shaped by influences such as gender expectations, social prestige, and the perceived difficulty of the career (Auger et al., 2005). Self-concept development for elementary-aged children includes three out of four stages:

1. Orientation to size and power (ages 3-5): Thought process is concrete; children develop some sense through sex roles of what it means to be an adult.

2. Orientation to sex roles (ages 6-8): Self-concept is influenced by gender development.

3. Orientation to social evaluation (ages 9-13): Development of concepts of social class contributes to the awareness of self-insituation. Preferences for level of work develop. 
In this model, occupational aspirations or preferences develop with the complexities of all other aspects of growth, thus, aspirations move from the simplistic during the very early stages of development to the more comprehensive into the later stages of early childhood into adolescence. Another important concept of Gottfredson's theory is the process of compromise in career decision-making. Gottfredson suggests that people compromise or create boundaries of acceptable careers based on perceived accessibility. This is significant at the elementary level, as school counselors can aid in the possibility of career foreclosure or elimination based on unclear self-concepts (Gottfredson, 1981; Mariani et al., 2016; Woods \& Kaszubowski, 2008).

Two additional theories, though less noted in the career development literature are those of Ginzberg (Ginzberg, 1952; Ginzberg et al., 1951) and Havighurst (1964). Ginzberg's theory of career development includes three periods of development, the first being the fantasy stage (birth-11 years of age). During this stage, children role play and imitate occupations based on fantasy. Toward the end of this stage, children begin to simulate specific job tasks related to those occupations as they transition to viewing their career aspirations more realistically (Ginzberg, 1951; Ginzberg et al., 1951). Similarly, Havighurst (1964) proposed six stages of career development. The first stage, identification with a worker, occurs during ages 5 to 10 , said to be the most critical stage when a child develops an understanding of the world of work in relation to his or her adult life. Attachment and connection to adults (i.e. parents/guardians, counselors, teachers) could aid in the identification of careers and career self-concept, thus, career-related interventions to assist students early on are critical. Such developmental theories provide a framework for the support of early career-related interventions at the elementary level.

\section{Professional Standards and Guidelines}

Both the American School Counseling Association (ASCA) and the College Board National Office for School Counselor Advocacy (NOSCA) have created clear standards and guidelines (ASCA, 2003; 2014, NOSCA, 2012) advocating for college and career readiness across $\mathrm{K}-12$ settings. Most notably is their attention to early career interventions beginning at the elementary level.

The American School Counseling Association's Mindsets \& Behaviors (2014) includes clear standards supporting the preparation for college and career readiness. Organized in three domains, one is dedicated to career development. The career development domain guides school counseling programs to help students 1) understand the connection between school and work, and 2) plan for and make a successful transition from school to post-secondary education and/or the world of work and from job to job across the lifespan (2014). All 35 standards categorized into mindsets and behaviors can be applied to each of the domains. Examples of mindset standards include a) understanding that postsecondary education and life-long learning are necessary for long-term career success, b) positive attitude toward work and learning, c) belief in using abilities to their fullest to achieve high-quality results and outcomes. Examples of behavior standards include a) identify long- and short-term academic, career and social/emotional goals, b) use time-management, organizational and study skills, and c) gather evidence and consider multiple perspectives to make informed decisions. While these standards provide guidance for school counselors, they lack direction when considering ways to utilize these standards at different grade levels (ASCA, 2014).

Prior to the creation of the Mindsets \& Behaviors standards, the American School Counselors Association provided recommendations related to the functions of elementary school counselors (Campbell \& Dahir, 1997). They included the implementation of effective classroom guidance activities (i.e, communication and decisionmaking skills; individual and small groups addressing topics such as self-image and self-esteem; academic and career assessments (Zunker, 2006).

The College Board National Office for School Counselor Advocacy (NOSCA) published the Eight Components of College and Career Readiness Counseling (NOSCA, 2012), providing a systemic approach for school counselors to implement. They include:

1. College Aspiration: goal of building an early college-going culture;

2. Academic Planning for College and Career Readiness: goal of advancing students' planning, preparation, and participation in rigorous academic programs that connect to college and career aspirations and goals;

3. Enrichment and Extracurricular Engagement: goal of equitable exposure to a wide range of extracurricular and enrichment opportunities that build leadership skills;

4. College and Career Exploration and Selection Processes: goal of providing early and ongoing exposure to experiences and information necessary to make informed decisions;

5. College and Career Assessments: goal of promoted preparation, participation, and performance in college and career assessments by all students;

6. College Affordability Planning: goal of providing students and families with comprehensive information about college costs, payment options, and the financial aid and scholarship process;

7. College and Career Admission Processes: goal of ensuring that students and families have an early and ongoing understanding of the college and career application processes;

8. Transition from High School Graduation to College Enrollment: goal of connecting students to school and community resources to help them overcome barriers and ensure successful transition (NOSCA, 2012). 
Components 1-6 are included for elementary school counselors. It is NOSCA's belief that elementary school counselors are in an especially critical role, encouraging early awareness, knowledge, and skills that lay the foundation for the academic rigor and social development needed for college and career readiness (NOSCA, 2012). Again, while thorough in explanation and guidance, few examples of best practices related to the incorporation of these components are provided.

Lastly, the National Career Development Association (NCDA) provides guidelines for elementary school counselors, including three focus areas: a) selfknowledge; b) educational and occupational exploration; and c) career planning. Some K-6 examples (Paisley \& Hubbard, 1994) include:

1. Kindergarten students will be able to describe what they like to do;

2. First-grade students will be able to identify workers in various settings;

3. Second-grade students will be able to describe skills needed to complete a task at home or school;

4. Third-grade students will be able to define what the term future means;

5. Fourth-grade students will be able to imagine what their lives might be like in the future;

6. Fifth-grade students will be able to discuss stereotypes associated with certain jobs;

7. Sixth-grade students will be able to identify their own personal strengths and weaknesses.

Existing College and Career Readiness Interventions

Career-related programs and interventions in elementary schools are considered essential to the overall educational experience of all students. Such programs should be intentional and strategic, utilizing theoretical frameworks and professional guidelines that support a holistic approach to college and career readiness at all levels (Auger et al., 2005; Blackhurst \& Auger, 2008; Mariani et al., 2016; Woods \& Kaszubowski, 2008). Developmental in nature, strong college and career readiness programs should consider activities and counseling strategies that are age-appropriate and should proactively involve key stakeholders, including school counselors, administrators, teachers, parents, and community members (Zunker, 2006.). While survey research has identified the need for early college and career readiness interventions into elementary curriculum, little to no evidence-based interventions exist that school counselors can implement (Mariani et al., 2016)

In a recent study featured in one of the leading school counseling journals in the U.S. (Mariani et al., 2016), a case study demonstrated how one elementary school counseling team used an interdisciplinary, collaborative approach to implement and evaluate a college and career readiness curriculum entitled, "Operation Occupation." This study sought to understand the impact of a college and career readiness curriculum unit used with fifth-grade students $(n=43)$. This intervention was intentionally aligned with the ASCA Mindsets and Behaviors standards and their state's common core standards. Counselors and teachers were involved in the planning and integration of this intervention over the course of one week and taught lessons on wants versus needs, learning styles, personality types, and job skills. In addition, a career fair was planned and teachers used a token economy system in their classrooms whereby students earned pretend money for good grades, appropriate behavior, and contributions to overall classroom engagement (Mariani et al., 2016). Results indicated an increase in students' knowledge and awareness of college and career readiness. While results from this study do not provide strong outcome data regarding students' behaviors toward college and career readiness, it was noted as highly beneficial to the students while creating a positive atmosphere in classrooms in which the interventions were incorporated.

Another example of a college and career readiness intervention is the Communities in Schools (CIS) project, a program which provides site coordinators to PK-12 schools in one district, who assist with establishing relations with local businesses, community agencies, and volunteers who can aide with college and career readiness programs. Results from CIS's internal research (Communities in Schools [CIS], 2015) showed an increase in student attendance, behavior improvement, and achievement level for those who participated in the program. An additional example, as cited in Mariani et al. (2016), include counselor-implemented interventions such as the Real Game Series, a K-16 curriculum that introduces students to the world of work and other career information, broken down into two small components for grades 3-4 and grade 5. Other notable programs, though limited in research support, are programs such as Project Grad, First Things First, and Believing the Dream.

\section{Discussion and Conclusion}

It is evident that the early exposure to career awareness and interventions beginning at the elementary level is critical to the college and career readiness of students. Since career development involves a life-long process that begins during early childhood, there is a clear need for evidence-based college and career readiness interventions for elementary students. Since the formation of personal and career self-concepts occur at such an early age, proactive and intentional guidance to support the exploration of careers while building college expectations should be further explored. For elementary school counselors to help students develop an early college-going mindset, further research citing evidence-based outcomes is necessary. Several theories suggest the importance of helping students during the formation of self-concept, including helping students become aware of their strengths and limitations, an introduction to the world of work, gender role expectations and moving from the fantasy stage of career aspirations to the creation of aspirations based 
on well-informed decisions (Ginzberg, 1952; Gottfredson, 1981; Havighurst, 1964; Super, 1990).

While the American School Counseling Association (ASCA), the College Board National Office for School Counselor Advocacy (NOSCA), and the National Career Development (NCDA) have provided helpful guidelines and strategies to assist elementary school counselors, limited outcome data exists. Existing strategies include the intentional collaboration between school counselors, teachers, and community partners to engage students in a variety of activities both in and out of the classroom. As the need for postsecondary education becomes even greater, early career interventions at the elementary level will become even more critical. Elementary school counselors are charged with a large, yet significant task, which serves as the impetus for all future college and career planning. As additional outcome data becomes available, elementary school counselors will be able to provide clearly established, evidence-based plans of action.

\section{References}

American School Counselor Association. (2003). The ASCA national model: A framework for school counseling programs. Alexandria, VA: Author.

American School Counselor Association (2014). Mindsets and behaviors for student success: $\mathrm{K}$-12 college-and career-readiness standards for every student. Alexandria, VA: Author.

Auger, R.W., Blackhurst, A.E., \& Wahl, K.H. (2005). The development of elementary-aged children's career aspirations and expectations. Professional School Counseling, 8(4), 322-329. Retrieved from https://bluehawk.monmouth.edu:2443/login?url=htt ps://bluehawk.monmouth.edu:4764/docview/21331 0863? accountid $=12532$

Blackhurst, A.E., \& Auger, R.W. (2008). Precursors to the gender gap in college enrollment: Children's aspirations and expectations for their futures. Professional School Counseling, 11(3), 149-158. doi:10.5330/PSC.n.2010-11.149

Campbell, C.A., \& Dahir, C.A. (1997). The national standards for school counseling programs. Alexandria, VA: American School Counseling Association.

Carnevale, A.P., Smith, N., \& Strohl, J. (June 2010). Help wanted: Projections of jobs and education requirements through 2018. Washington, DC: Georgetown University Center on Education and the Workforce. Retrieved from https://cew.georgetown.edu/cewreports/help-wanted/

Carnevale, A.P., Smith, N., \& Strohl, J. (2014). Recovery: Job growth and education requirements through 2020. Washington, DC: Georgetown University Center on Education and the Workforce. Retrieved from https://repository.library.georgetown.edu/bit stream/handle/10822/559311/Recovery2020.FR.We b.pdf?sequence $=1$
Communities in Schools. (2015). Fall 2015 Annual Report. Retrieved fromhttp://www.communitiesinschools org/about/publications/publication/national-impactreport-fall-2015

Ginzberg, E. (1952). Toward a theory of occupational choice. Occupations, 30, 491-494.

Ginzberg, E., Ginsburg, S.W., Axelrad, S., \& Herma, J.L. (1951). Occupational choice: An approach to a general theory. New York: Columbia University Press.

Gottfredson, L.S. (1981). Circumscription and compromise: A developmental theory of occupational aspirations. Journal of Counseling Psychology Monograph, 28, 545-579.

Havighurst, R. (1964). Youth in exploration and man emergent. In H. Borow (Ed.), Man in a world at work (pp.215-236). Boston: Houghlin Mifflin.

Knight, J.L. (2015). Preparing elementary school counselors to promote career development: Recommendations for school counselor education programs. Journal of Career Development, 42(2), 7585. doi: $10.1177 / 0894845314533745$

Mariani, M., Berger, C., Koerner, K., \& Sandlin, C. (2016). Operation occupation: A college and career readiness intervention for elementary students (Practitioner-focused research). Professional School Counseling, 20(1), 65-76. doi:10.5330/1096-240920.1 .65

Niles, S.G., \& Harris-Bowlsbey, J. (2005). Career development interventions in the $21^{\text {st }}$ century (3rd ed.). Saddle River, NJ: Pearson Education.

National Office for School Counselor Advocacy. (2012). Elementary school counselor's guide: NOSCA's eight components of college and career readiness counseling. New York, NY: The College Board.

Paisley, P.O., \& Hubbard, G.T. (1994). Developmental school counseling programs: From theory to practice. Alexandria, VA: American Counseling Association.

Parsons, F. (1909). Choosing a vocation. Boston: Houghton Mifflin.

Reach Higher. (2015). Reach Higher Initiative. Retrieved from https://obamawhitehouse.archives.gov/reachhigher

Seligman, L., Weinstock, L., \& Heflin, E.N. (1991). The career development of 10 year olds. Elementary School Guidance \& Counseling, 25, 172-181.

Super, D. E. (1990). A life-span, life-space, approach to career development. In D. Brown \& L. Brooks (Eds.), Career choice and development. San Francisco, CA: Jossey-Bass.

Trice, A.D., \& McClellan, N. (1994). Does childhood matter? A rationale for the inclusion of childhood theories of career decision. California Association for Counseling and Development Journal, 14, 35-44.

Wood, C., \& Kaszubowski, Y. (2008). The career development needs of rural elementary school 
students. The Elementary School Journal, 108 (5), 431 444.

Zunker, V.G. (2006). Career counseling: A holistic approach ( $7^{\text {th }}$ ed.). Belmont, CA: Thomson-Brooks Cole. 